RESEARCH ARTICLE

\title{
Diversity and distributional ecology of tree ferns of Sri Lanka: A step towards conservation of a unique gene pool
}

\author{
R.H.G. Ranil ${ }^{1, *}$, D.K.N.G. Pushpakumara1 ${ }^{1}$, D.S.A. Wijesundara ${ }^{2}$, P.D. Bostock ${ }^{3}$, A. Ebihara ${ }^{4}$ and \\ C.R. Fraser-Jenkins ${ }^{5}$ \\ ${ }^{1}$ Department of Crop Science, Faculty of Agriculture, University of Peradeniya, Peradeniya, Sri Lanka. \\ ${ }^{2}$ National Institute of Fundamental Studies, Hantana Road, Kandy, Sri Lanka. \\ ${ }^{3}$ Queensland Herbarium, Mount Coot-tha Road, Toowong, QLD 4066, Australia. \\ ${ }^{4}$ Department of Botany, National Museum of Nature and Science, Amakubo 4-1-1, Tsukuba, Ibaraki 305-0005, Japan. \\ ${ }^{5}$ Student Guest House, Thamel, P.O. Box 5555, Kathmandu, Nepal.
}

Received: 23/12/2016; Accepted:07/09/2017

\begin{abstract}
Tree ferns are a remarkable group among the lycophytes and ferns. Geographical isolation is suggested as one of the main reasons for local endemism of tree ferns and the island of Sri Lanka has been identified as one of the best demonstration sites to observe this phenomenon. Despite its small size, Sri Lanka has a rich diversity and one of the highest levels of endemism of tree ferns in Asia. Their diversity here is considered as an unique and important gene pool in the world. The present eco-spatial survey is to study the diversity and ecology of tree ferns in Sri Lanka.

The study identified nine tree fern species including one new record of an adventive species. The species are Cyathea hookeri, C. sinuata, C. sledgei, C. srilankensis, C. walkerae, C. crinita, C. gigantea, C. australis and Dicksonia antarctica. Of these, the first five species are endemic to Sri Lanka. Dicksonia antarctica and Cyathea australis are exotic and naturalised in forest clearings in Piduruthalagala forest. Cyathea hookeri, C. sinuata, C. sledgei and $C$. srilankensis are confined to limited populations in lowland rainforests $(62-550 \mathrm{~m})$. Cyathea walkerae is distributed in a wide elevational range throughout the wet zone $(30-2,300 \mathrm{~m})$, whereas C. crinita shows a restricted distribution pattern at a high altitude range (1,800-2,400 m). In this study $C$. gigantea was recorded additionally from lowland rain forests, though it was previously reported to be confined to submontane and montane ecosystems. The results of this study provide baseline information on the distributional ecology of Sri Lankan Cyathea species. It will be useful to assess their current conservation status and to formulate conservation guidelines for these remarkable and spectacular ferns so characteristic to Sri Lanka.
\end{abstract}

Keywords: Tree ferns, Cyathea, diversity, endemism.

\section{INTRODUCTION}

Tree ferns are usually placed in two families namely, Cyatheaceae and Dicksoniaceae, which are both ancient families placed relatively early in taxonomic classifications and from among which several major modern lineages of ferns are derived. The family Cyatheaceae has a wide pan-tropical geographical distribution combined with pronounced local endemism (Tryon and Gastony 1975). It contains about 500 species worldwide with diversity centres in tropical rain forests (Holttum, 1963, 1965, 1981; Conant et al. 1996; Tryon and Gastony, 1975). Geographical isolation is suggested as one of the main reasons for local endemism (Tryon and Gastony 1975), and we identified here that Sri Lanka with its relict island flora as one of the best demonstration sites to observe this phenomenon.

Despite its small size, Sri Lanka has a rich diversity and one of the highest levels of endemism of tree ferns in Asia. We prefer to use the genus Cyathea in an inclusive sense here, recognising their similar morphology, rather than splitting it into its constituent minor genera, Alsophila and Sphaeropteris. Sri Lankan tree ferns are now known to consist of eight Cyathea species (Cyatheaceae) and one Dicksonia species (Dicksoniaceae). Of the seven native species, five (Cyathea sinuata Hook. \& Grev., Cyathea hookeri Thwaites, Cyathea sledgei Ranil, Pushpak. and Fraser-Jenk., Cyathea walkerae Hook. and Cyathea srilankensis Ranil) are endemic to Sri Lanka and two species (Cyathea crinita (Hook.) Copel. and Cyathea gigantea (Wall. ex Hook.) Holttum) are native to the island but also distributed elsewhere $(C$. crinita is only known otherwise from South India, and $C$. gigantea is a wide spread Malesian element in south and east Asia). Cyathea australis (R.Br.) Domin and, Dicksonia antarctica Labill. are introduced. They are widely cultivated exotic species which have now become naturalised. There is thus considerable diversity in the island and the species present also include a great range of remarkable morphological diversity.

However, information on Sri Lankan tree ferns has so far been almost entirely limited to lists of species and their morphological descriptions (Hooker, 1846; Hooker \& Baker, 1865; Thwaites, 1864; Beddome, 1883; Holttum, 1965; Ashton et al., 1997; Philcox, 2006). But since conservation or management of species is based on levels of threat, frequency of occurrence and ecological factors, information on morphological and genetic variation in different areas, taxonomy, cytology, population-ecology, reproductive biology and distribution is essential and we attempt to provide basic information on them in this study. The present eco-spatial survey was conducted as Ranil et al. (2011) highlighted the necessity to study the distribution patterns of tree ferns in Sri Lanka for their management and conservation perspectives. 


\section{METHODOLOGY}

\section{Distribution and mapping}

A local eco-distributional survey was conducted covering 42 forests in 10 administrative districts in the country. The forest ecosystems including Proposed Forest Reserves (PR), Forest Reserves (FR), Man and Biosphere Reserves (MAB), World Heritage Sites (WHS) and National Parks (NP) were selected based on the literature and existing herbarium specimens. The forests surveyed are listed in Table 1. The stream network, forest gaps and boundaries and roadside banks of each forest ecosystem were identified as sampling points. Specimens were collected according to standard herbarium techniques. Distribution maps for each species were prepared using GIS technology.

\section{Ecology, habitat requirements and threats}

Data on habitat requirements, ecological niches and threats were obtained through direct observation and interviews with peripheral communities as well as with officers of the Forest Department and Department of Wildlife Conservation, where appropriate.

\section{RESULTS AND DISCUSSION}

\section{Diversity of tree ferns in Sri Lanka}

The study catalogued eight Cyathea species (C. crinita, $C$. walkerae, C. gigantea, C. sinuata, C. hookeri, C. sledgei, C. srilankensis and C. australis) and one Dicksonia species (D. antarctica) from natural ecosystems in Sri
Lanka. Other than the historical locality at the fernery in Hakgala Botanic Garden, the only known naturalised wild population of Dicksonia antarctica is in Piduruthalagala Mountain and in the adjacent Eucalyptus plantation (Ranil et al., 2014). Furthermore, we were also able to record a substantial and well-established naturalized population of Cyathea australis, including more than 100 mature individual plants. It is suspected that like a number of other introductions, this species was introduced to Hakgala Botanic Garden during the colonial era and later may have escaped from the garden. The study recorded all previously identified Sri Lankan Cyathea taxa except Cyathea walkerae var. tripinnata Hook. \& Baker. Table 2 shows the species diversity of tree ferns in Sri Lanka with their geographical occurrence and conservation status based on the National Red List 2012 (MOE, 2012). Plates 1, 2 and 3 show Sri Lankan tree fern species recorded during the eco-geographic survey. Holttum (1981) suggested an affinity of some Sri Lankan Cyathea species with African counterparts, and although Janssen et al. (2008) and Korall and Pryer (2014) suggested that the Sri Lankan species they investigated showed no close affinities with African species studied, although there may still be some phytogeographical connection.

\section{Distribution}

Table 3 shows the summarised information on the distribution of different tree fern species in Sri Lanka. All the sample points lie in the wet zone of the island and the southern and central provinces show relatively high

Table 1: List of forest reserves in Sri Lanka where the study was carried out.

\begin{tabular}{|c|c|c|}
\hline $\begin{array}{l}\text { Administrative } \\
\text { district }\end{array}$ & $\begin{array}{l}\text { Names of } \\
\text { forest reserves }\end{array}$ & $\begin{array}{c}\text { Forest types and } \\
\text { maximum elevation } \\
\text { studied } \\
\end{array}$ \\
\hline Nuwara Eliya & $\begin{array}{l}\text { Hakgala Strict Nature Reserve, Horton Plains National Park, } \\
\text { Kikiliyamana Forest, Adam's Peak Wilderness, Kirigalpotta } \\
\text { Mountain, Piduruthalagala Forest }\end{array}$ & $\begin{array}{l}\text { Montane and } \\
\text { submontane. } 2,237 \mathrm{~m}\end{array}$ \\
\hline Badulla & $\begin{array}{l}\text { Udakeeruwa Proposed Forest, Namunukula Forest, Thangamalai } \\
\text { Sanctuary }\end{array}$ & $\begin{array}{l}\text { Lowland and montane. } \\
2,719 \mathrm{~m}\end{array}$ \\
\hline Kalutara & $\begin{array}{l}\text { Kalugala Forest Reserve, Runakanda Forest Reserve, Wathurana } \\
\text { Swamp Forest, Kukuleganga Forest, Dombagaskanda Forest }\end{array}$ & Lowland. $203 \mathrm{~m}$ \\
\hline Kurunegala & Hadurukkanda Forest, Dolukanda Forest Reserve & Lowland. $339 \mathrm{~m}$ \\
\hline Gampaha & Horagolla National Park & Lowland. $71 \mathrm{~m}$. \\
\hline Kandy & $\begin{array}{l}\text { Galaha Forest Reserve, Hunnasgiriya Forest, Loolkandura Forest, } \\
\text { Udawattakele Forest Reserve, Hantana Forest and Gannoruwa Forest }\end{array}$ & $\begin{array}{l}\text { Lowland and } \\
\text { submontane. } 1,455 \mathrm{~m}\end{array}$ \\
\hline Matale & Knuckles Conservation Forest & $\begin{array}{l}\text { Lowland, submontane } \\
\text { and montane. } 1,852 \mathrm{~m} \text {. }\end{array}$ \\
\hline Galle & $\begin{array}{l}\text { Kanneliya MAB Reserve, Hiniduma Forest Reserve, Kottawa } \\
\text { Forest Reserve, Dellawa Forest Reserve, Nakiyadeniya Forest } \\
\text { Reserve, Dediyagala Forest Reserve, Beraliya Proposed Forest and } \\
\text { Polgahakanda Forest }\end{array}$ & Lowland. $560 \mathrm{~m}$ \\
\hline Matara & $\begin{array}{l}\text { Sinharaja World Heritage Site, Mulatiyana Forest Reserve, } \\
\text { Oliyagankele Forest Reserve, Enasalwatta Forest }\end{array}$ & Lowland. $285 \mathrm{~m}$ \\
\hline Ratnapura & $\begin{array}{l}\text { Sinharaja World Heritage Site, Gilimale Forest, Erathna Forest, } \\
\text { Walankanda Forest } \\
\text { Rassagala Forest, Pettigala Forest }\end{array}$ & Lowland. $772 \mathrm{~m}$ \\
\hline
\end{tabular}


population densities of some species (Figure 1A). Cyathea sinuata and $C$. hookeri were recorded previously only from three southern lowland rain forest areas (Kanneliya FR, Sinharaja WHS and Beraliya PR) confined to a few known populations. The present survey records both $C$. sinuata and $C$. hookeri from fragmented forests in the south-west of the country as a few isolated patches in the Hiniduma Forest Reserve and Runakanda PR (Figure1B). Cyathea walkerae has a wide distribution throughout the wet zone (Figure 1C). It occurs commonly in open areas of roadside banks and nearby streams. Cyathea crinita has a restricted distribution pattern at high altitude. It is restricted to Nuwara Eliya district (Figure 1D) and is mostly confined to roadside banks. According to previous records, $C$. gigantea is limited to the montane region, but the present study has revealed that it also occurs in lowland rain forest.

Cyathea srilankensis considered to be a point (very narrow distribution) endemic, confined to two small populations at its type locality at the Sinharaja WHS and a substantial population of C. srilankensis in Beraliya PR. Cyathia sledgei also has a very narrow distribution, confined to two southern lowland rain forests (Sinharaja MAB Reserve and Kanneliya FR). Dicksonia antarctica and Cyathea australis occur as naturalised exotic escapes into the natural environment only on Pidurutalagala Mountain in the central highlands of the island. We could find no

Table 2: Recorded distributional range of tree fern species from montane, submontane and lowland rain forests of Sri Lanka.

\begin{tabular}{|c|c|c|}
\hline Species & $\begin{array}{l}\text { Geographical } \\
\text { status }\end{array}$ & $\begin{array}{c}\text { National } \\
\text { Conservation } \\
\text { status }\end{array}$ \\
\hline 1. Cyathea sinuata Hook. \& Grev. & Endemic to Sri Lanka & Endangered \\
\hline 2. Cyathea hookeri Thwaites & Endemic to Sri Lanka & $\begin{array}{l}\text { Critically } \\
\text { endangered }\end{array}$ \\
\hline $\begin{array}{l}\text { 3. Cyathea sledgei Ranil, Pushpak. \& } \\
\text { Fraser-Jenk. }\end{array}$ & Endemic to Sri Lanka & Endangered \\
\hline 4. Cyathea walkerae Hook. & Endemic to Sri Lanka & Vulnerable \\
\hline 5. Cyathea srilankensis Ranil & Endemic to Sri Lanka & Endangered \\
\hline 6. Cyathea crinita (Hook.) Copel. & Native to S. India and Sri Lanka & Endangered \\
\hline $\begin{array}{l}\text { 7. Cyathea gigantea (Wall. ex Hook.) } \\
\text { Holttum }\end{array}$ & $\begin{array}{l}\text { Native to Sri Lanka, China, N., C. and S. India, Nepal, } \\
\text { Bhutan, Bangladesh, Myanmar, Thailand, Laos, } \\
\text { Cambodia, Vietnam, Malaysia and Indonesia }\end{array}$ & Endangered \\
\hline 8. Cyathea australis (R.Br.) Domin & Naturalised in Sri Lanka, native to Australia & Not assessed \\
\hline 9. Dicksonia antárctica Labill. & Naturalised in Sri Lanka; native to Australia & Not assessed \\
\hline
\end{tabular}

Table 3: Distribution patterns of tree ferns in Sri Lanka according to their ecological and habitat requirements.

\begin{tabular}{|c|c|c|c|c|}
\hline Species & $\begin{array}{l}\text { Elevation } \\
\quad(\mathbf{m})\end{array}$ & $\begin{array}{l}\text { Agro-climatic } \\
\text { zone }\end{array}$ & $\begin{array}{l}\text { Forest } \\
\text { type }\end{array}$ & $\begin{array}{l}\text { Most common } \\
\text { micro-habitats }\end{array}$ \\
\hline Cyathea crinita & $1,800-2,400$ & WU & Montane & $\begin{array}{l}\text { Roadsides, under storey of } \\
\text { Eucalyptus plantation }\end{array}$ \\
\hline Cyathea gigantea & $80-1,600$ & WL,WM,WU & $\begin{array}{l}\text { Lowland, } \\
\text { submontane, Montane }\end{array}$ & Roadsides \\
\hline Cyathea hookeri & $62-550$ & WL & Lowland & Stream banks \\
\hline Cyathea sinuata & $62-550$ & WL & Lowland & Stream banks \\
\hline Cyathea sledgei & $80-550$ & WL & Lowland & Stream banks \\
\hline Cyathea srilankensis & $62-550$ & WL & Lowland & Stream banks \\
\hline Cyathea walkerae & $30-2,300$ & WU & $\begin{array}{l}\text { Lowland, } \\
\text { Submontane, Montane }\end{array}$ & Stream banks, roadsides \\
\hline Cyathea australis & $2,000-2,200$ & WL,WM,WU & Montane & $\begin{array}{l}\text { Under storey of } \\
\text { Eucalyptus plantation, } \\
\text { forest margin }\end{array}$ \\
\hline Dicksonia antarctica & $2,000-2,200$ & WU & Montane & $\begin{array}{l}\text { Under storey of } \\
\text { Eucalyptus plantation, } \\
\text { forest margin }\end{array}$ \\
\hline
\end{tabular}

Note: WL: wet zone low country; WM: wet zone mid country; WU: wet zone up country; IML: intermediate zone low country; IMM: intermediate zone mid country; IMU: intermediate zone up country; DL: dry zone low country. 

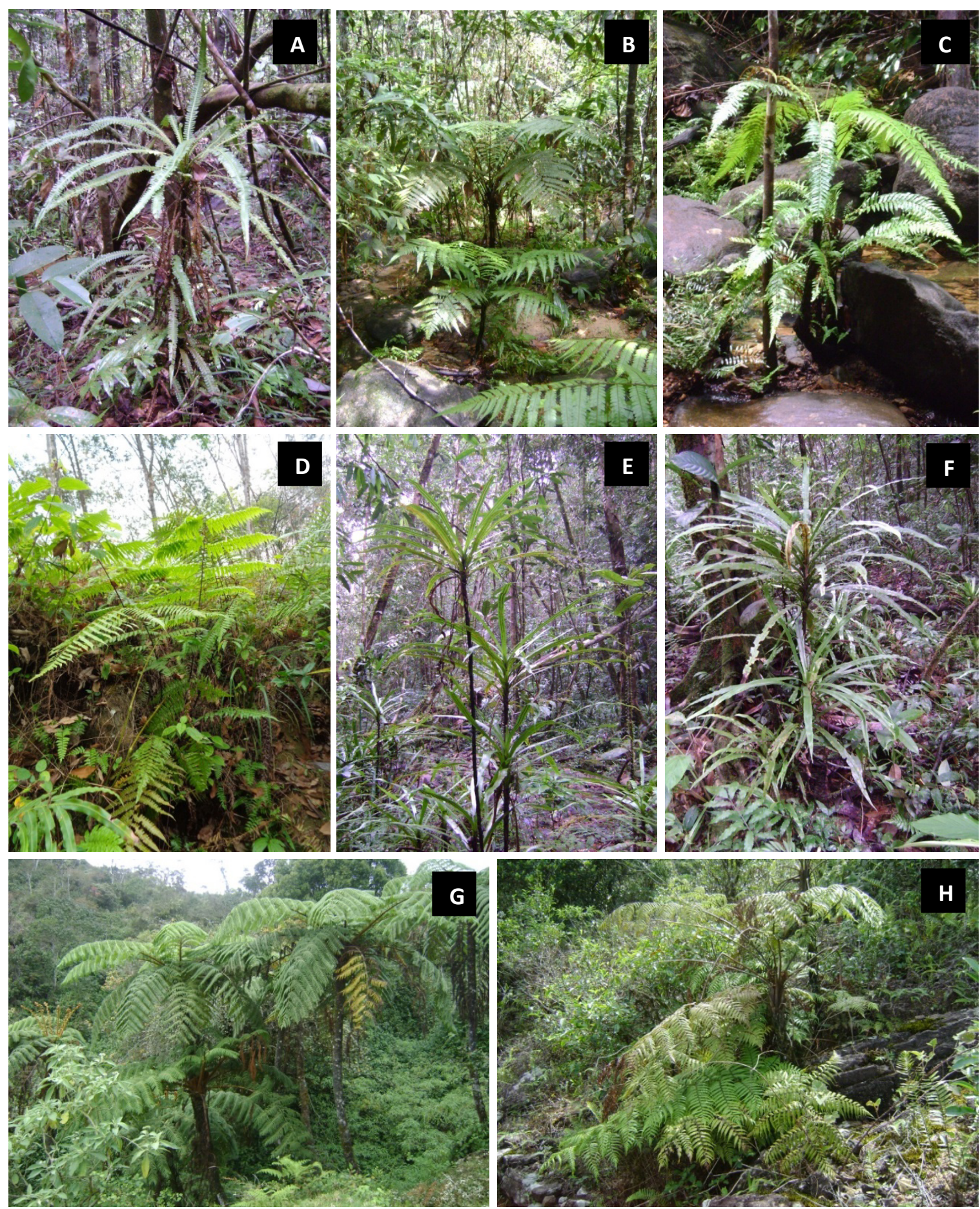

Plate 1A. Cyathea sledgei in Kanneliya Forest Reserve (FR). B: Cyathea srilankensis in Beraliya Proposed FR. C: Cyathea hookeri in Kanneliya FR. D: Cyathea gigantea in Udakeeruwa FR. E: Cyathea sinuata in Sinharaja WHS. F: Variant of Cyathea sinuata in Sinharaja WHS. G: Cyathea crinita in Horton Plains NP. H: Cyathea walkerae in Knuckles Conservation Forest. 

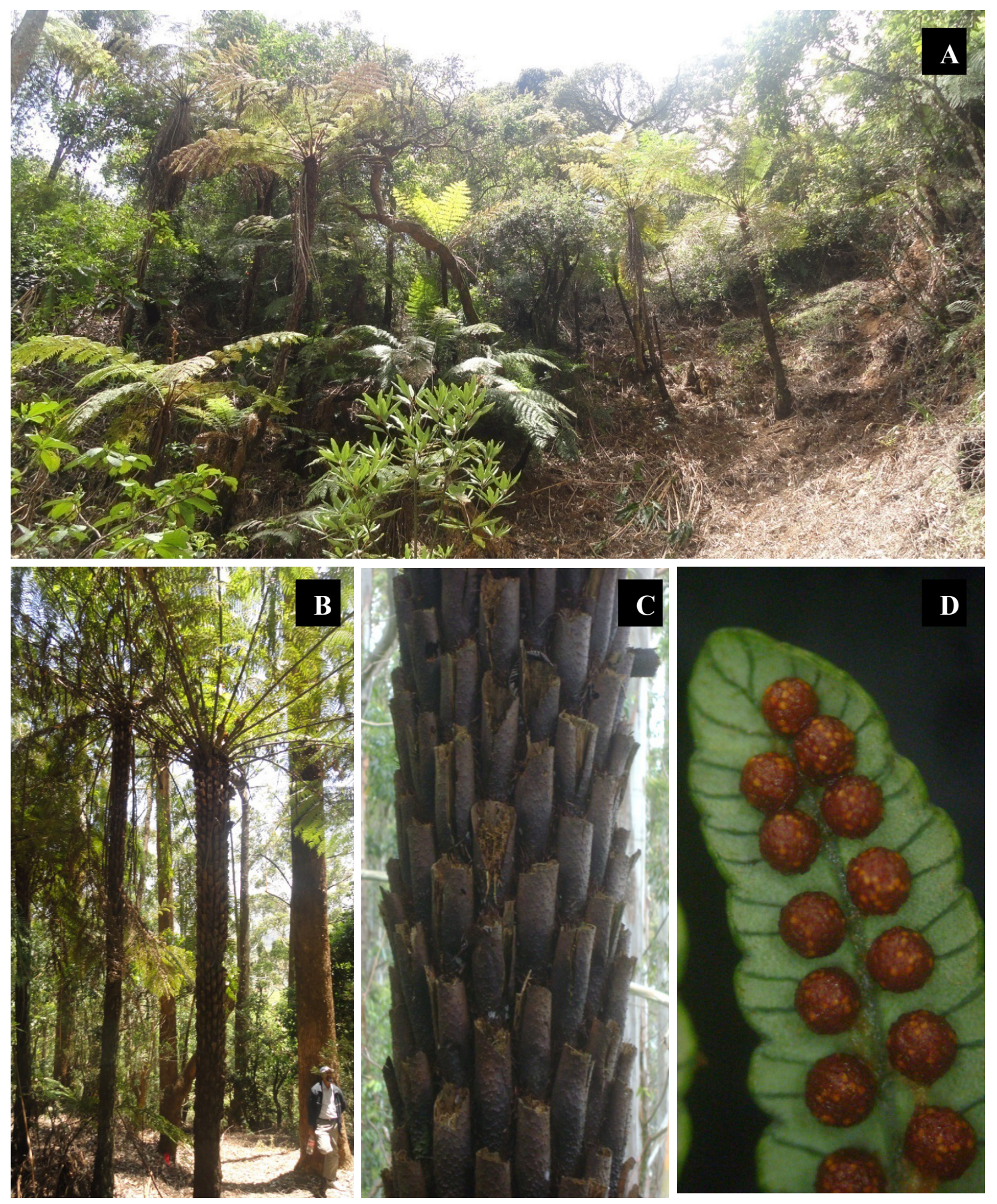

Plate 2A. Well established Cyathea australis population at Pidurutalagala Mountain. B: Mature individual about seven meters tall. C: Persistent petiole bases. D: Arrangement of sori. 

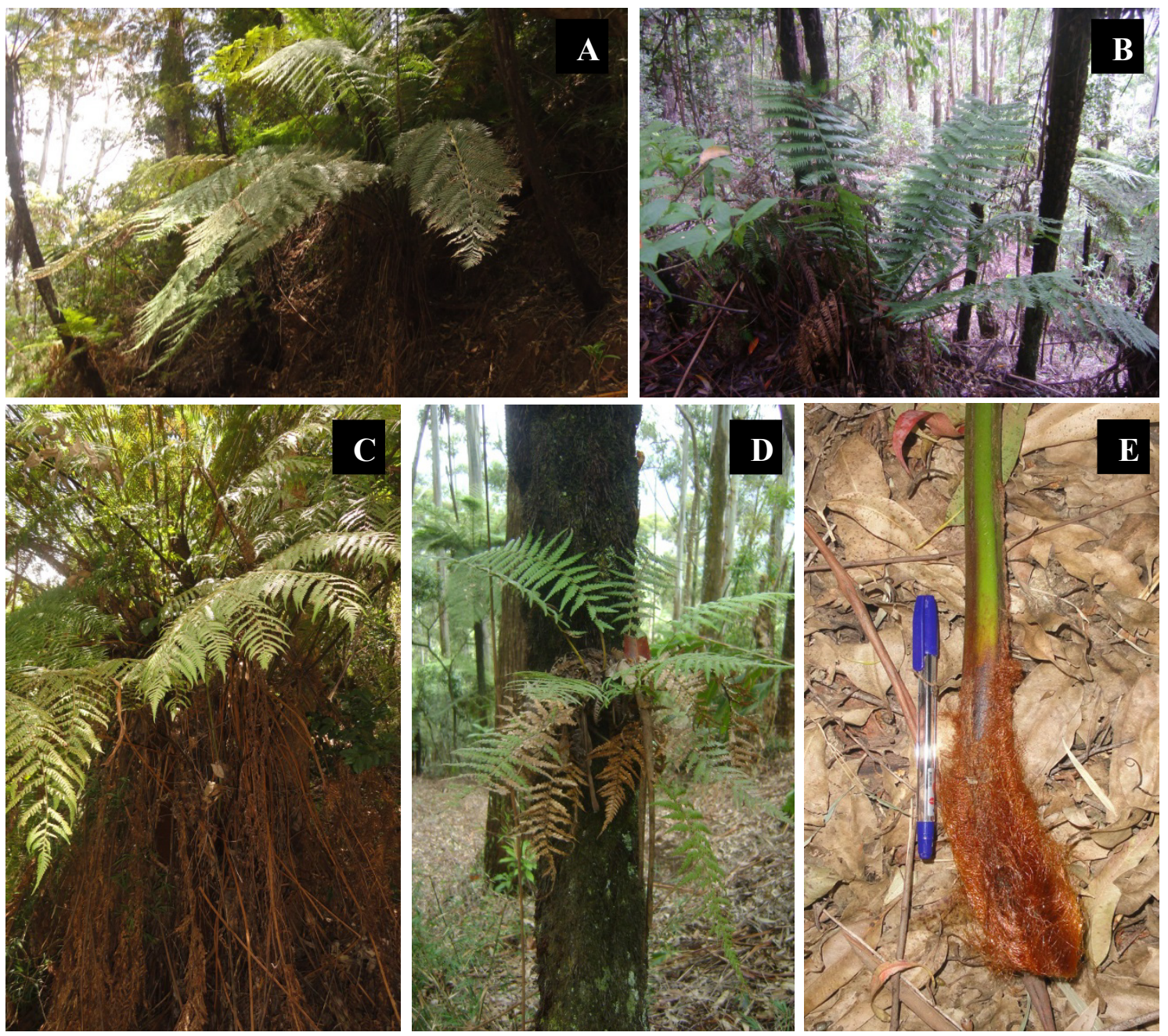

Plate 3A. Mature individual of Dicksonia antarctica Piduruthalagala Mountain. B: Juvenile plant growing in a Eucalyptus plantation. C: Plant with pendent dead fronds. D: Plant growing as an epiphyte. E: Frond base densely covered with glossy ginger-brown hairs.

information as to whether or when an initial plant might at some stage have been planted there, perhaps in connection with the presence of the Army there, or alternatively and more likely, whether they arrived by wind-dispersal from Hakgala, where they have both been under cultivation for a long time. According to the results obtained from this study, all tree-fern species in Sri Lanka, apart from the more widespread $C$. gigantea and $C$. walkerae, are areaspecific and each confined to a few localities.

\section{Ecological and habitat requirements}

The ecological and habitat requirements of each species were recorded from direct observation in the field. In Table 3 the summarised information about their ecology and habitats where they were usually found are given.

All these species are confined to the wet zone of Sri Lanka. However, these four species co-occur with each other and are limited to relatively small populations in tropical lowland rainforests. The habitat of these four normally terrestrial species is generally highly localised in the spray zones of fast flowing streams, which indicate that they prefer a highly moist environment. Even though these tree ferns are typically terrestrial, some individuals of $C$. sinuata were observed on lithophytic habitats on rocky streamside banks. The populations of the above species show scattered distribution patterns. They are confined to low altitudes ( $c a .62-550 \mathrm{~m}$ ) (Figure 1B) and immediately become scarce and then absent with increasing elevation. Of the four species, only $C$. sinuata is relatively common and shows pockets of distribution along water courses, forming dense populations.

The largest populations of $C$. sinuata, $C$. hookeri and $C$. sledgei were recorded from the Sinharaja WHS and the few other known localities had small populations. The mean annual rainfall at Sinharaja WHS is $5,006 \mathrm{~mm}$, whereas the other recorded localities have a much lower mean annual rainfall. Light level, canopy density and flow rate of streams change substantially with time and climatic factors. Stream banks are usually more exposed to direct sunlight than other places in the rainforest. Many fern species are therefore concentrated in such localities. This requirement correlates with the known distribution of tree fern species. These species usually prefer soil with more organic matter, but $C$. sinuata thrives well even on rocky stream side banks. Although the species studied in Sri Lanka are grown fully and had fully fertile fronds, producing spores abundantly, 

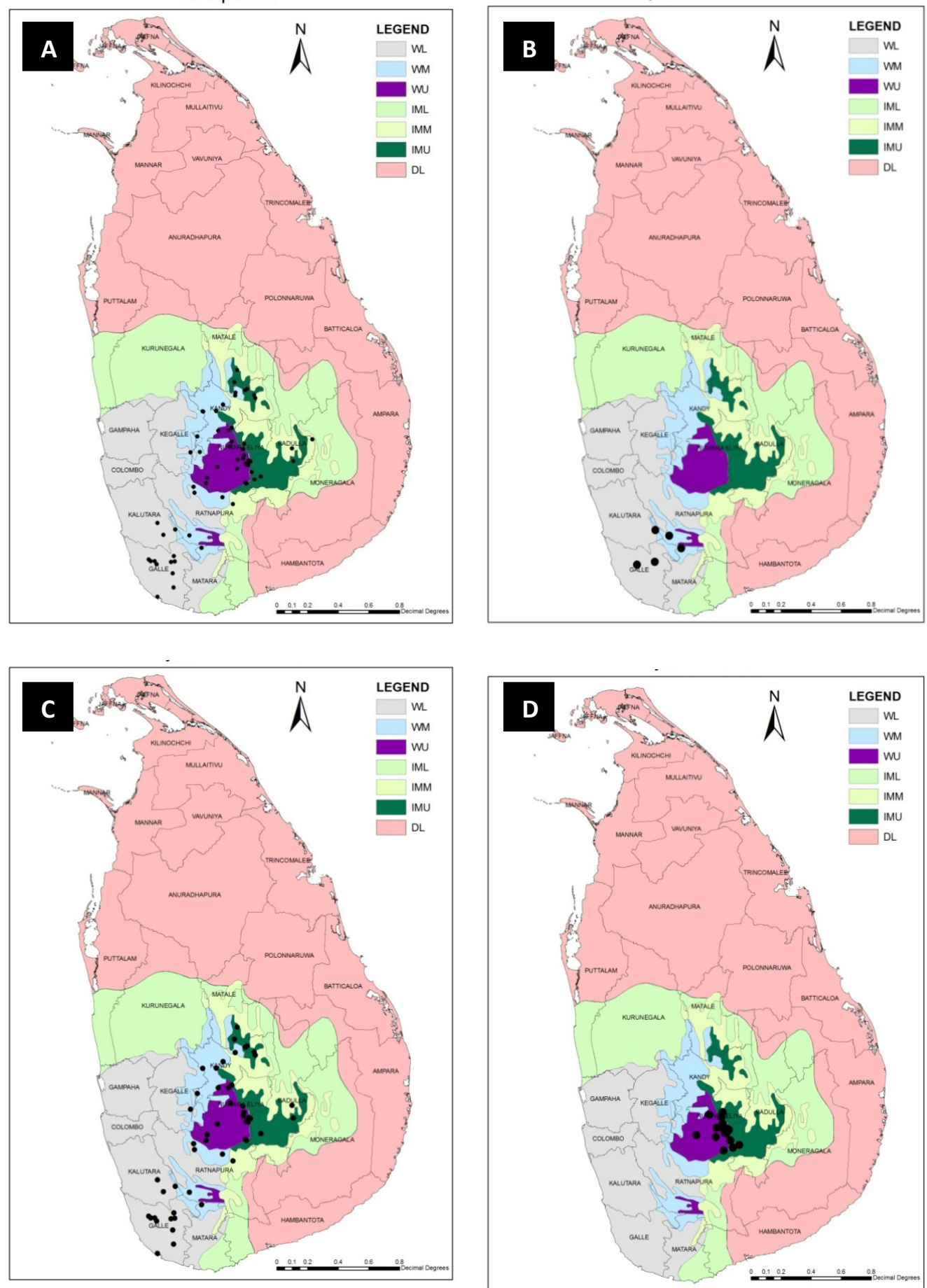

Figure 1. A: Distribution of tree fern species in Sri Lanka. B: Restricted distribution of the endemic and threatened C. sinuata and C. hookeri in lowland rain forests. C: Wide distribution of C. walkerae. D: Localised distribution of C. crinita. Cyathea hookeri, C. sinuata, C. sledgei and C. srilankensis

the reasons for their localised and patchy distribution are yet to be identified.

\section{Cyathea walkerae}

This is the most common and widespread tree fern species in Sri Lanka. Our survey shows that C. walkerae is distributed from 30 to $2,300 \mathrm{~m}$ altitude, thus inhabiting lowland, submontane and montane forests in Sri Lanka. It can thrive well in a wide range of climatic, topographical and edaphic conditions. Its most common habitats are roadside banks and among streamside vegetation in disturbed forests. It usually prefers $20-40 \%$ shade but is sometimes found surviving in fully open areas.

\section{Cyathea gigantea}

According to previous records and herbarium specimens, C. gigantea was thought to be limited to high altitude forests in the Central Province (Matale, Kandy and Nuwara Eliya districts). In the present investigation we recorded $C$. gigantea from southern lowland rain forest too, as is well known in other regions within its range. Its distribution ranges from 80 to $1,600 \mathrm{~m}$, usually a single population consists of one or two plants. The most preferred habitat is 
roadside banks in secondary vegetation or highly disturbed areas. It usually prefers $50-60 \%$ shade level and a substrate with high organic matter content.

\section{Cyathea crinita}

This species was observed only in forests at high altitude $(1,800-2,400 \mathrm{~m})$ in the Nuwara Eliya district. Within the district, it has a scattered distribution and is mainly confined to Horton Plain National Park and adjacent areas. The species usually prefers cool temperatures and high humidity and thrives well under direct sunlight. But a few small populations were also observed within Eucalyptus plantations. Climatic conditions in Nuwara Eliya region presumably represent ideal conditions for its growth and survival (Temperature: $3-15{ }^{\circ} \mathrm{C}$; Annual rainfall: 2,300 mm; RH: 75-90\%). Manickam and Irudayaraj (1992) have identified its habitat as shrub-savannas and in open forest streams between 1,500-2,200 $\mathrm{m}$ in south India (Palni Hills, Munnar Hills and Anamalai Hills), the only other area of its geographical range.

\section{Cyathea australis and Dicksonia antarctica}

Well established naturalised populations of C. australis and $D$. antarctica were recorded from Pidurutalagala Mountain FR and an adjacent Eucalyptus plantation (Ranil et al., 2014). The species inventory of the Hakgala Botanic Gardens shows that these two species were introduced into Hakgala Botanic Garden at least 120 years ago. They have evidently now escaped from the garden and are well established in the adjacent forest. The cool montane microclimate and high elevation $(1,745 \mathrm{~m})$ of Hakgala Botanic Garden evidently match the ecological requirements of $D$. antarctica. This may be the main reason why $D$. antarctica was able to be introduced successfully into the fernery at the garden during the colonial era, as a species of considerable ornamental appeal. A similar micro-climatic environment also occurs in Pidurutalagala Mountain FR and in an adjacent Eucalyptus plantation. Both the natural forest area and Eucalyptus plantation consist of nearly 40-50\% canopy cover and 20-30\% steepness (Ranil et al., 2014). Both species appear to have similar microecological requirements.

Ecological assessment is a continuous process. Detailed close observation and continuous monitoring at consecutive intervals are essential to draw firm conclusions. Many ecological parameters, such as temperature, light level, moisture and shade levels are highly variable over time. Continuous and long term assessment is therefore necessary to identify the detailed ecological requirement of each species.

\section{Conservation perspectives}

All tree fern species are confined to primary and secondary forest sites of the wet zone of Sri Lanka. Most of the forests remaining in the wet zone are now fragmented and small in extent. They continue to be degraded due to illegal destructive activities, suffering further fragmentation due to higher human population density in such areas. Further, the areas are highly subject to habitat loss, soil erosion, environmental pollution and the spread of alien invasive species into disturbed areas. These problems will be worsened by local changes of climate/rainfall and increasing human population pressure.

The survey revealed that four Cyathea species ( $C$. sinuata, C. hookeri, C. srilankensis and C. sledgei) are confined to a few known lowland rain forests and the population size of each of these species is small. All these forests are within the protected area network; and Sinharaja WHS and Kanneliya MAB reserve are highly protected, with no identified threats to their existing populations except the effect of local climatic change. Beraliya forest is a Proposed Reserve (PR) surrounded by highly urbanised cities and villages. These peripheral communities depend directly on the forest to meet some of their requirements, such as wood, fodder etc. Thus, the Cyathea populations in Beraliya PR are under considerable threat. Other small populations of $C$. sinuata and $C$. hookeri were observed in Runakanda PR in Kalutara district. These are under minimal threat from the surrounding community. Upgrading the current conservation status of these two forests is recommended to enhance the conservation of what is left of these magnificent forests, and the rare and threatened species and other animals and plants inhabiting them.

The main habitat of Cyathea walkerae, C. gigantea and C. crinita is roadside embankments, where their existing populations are unprotected and vulnerable to exploitation. The local people are unaware of their conservation value and ecological importance. This is a major impediment for their protection. People collect tree fern trunks directly from the wild from forest reserves as a support for growing orchids. They use the mature or semi-mature tree ferns, as ornamental plants in outdoor landscaping, thus destroying their natural populations, rather than from sustainable and responsible cultivation from spores, Cyathea crinita, confined to high altitude forests is also collected by communities. Though it is protected by several local and international laws, people continue to collect them from the wild without hindrance and at an increasing rate despite its dwindling populations.

The ultimate objective of this study is to provide ecological and distributional information on each species for their management and conservation. Members of the family Cyatheaceae are considered to be one of the most endangered plant groups among pteridophytes. Considering their biological importance as spectacular plants of great beauty and the unprecedented rate of threat to their associated natural ecosystems, all members of the family Cyatheaceae have been included in Appendix II of the Convention on International Trade in Endangered Species of Wild Fauna and Flora (CITES) in 1975. Furthermore, all tree fern species in Sri Lanka are protected by the Fauna and Flora Protection Ordinance and categorised as threatened species based on Red-listing criteria. Conservation biologists have therefore paid special attention to protect this important group of plants worldwide by providing legal measures to aid their conservation. But it is evident that the measures taken are not applied/enforced successfully in preventing 
destruction of tree ferns as the message has not been properly disseminated or enforced locally among adjacent communities, schools, rural villages etc. Local commercial enterprises or people with gardens found contravening/ flouting the laws are not being actively inspected and prosecuted. New measures are needed to actively enforce the laws enacted to protect tree ferns, which will also aid conservation of other threatened groups in general.

\section{CONCLUSIONS}

This study identified seven native tree fern species (Cyathea hookeri, C. sinuata, C. sledgei, C. srilankensis, $C$. walkerae, $C$. crinita and $C$. gigantea), including five endemic species and two adventive species ( $C$. australis and Dicksonia antarctica). Cyathea hookeri, C. sinuata, C. sledgei and C. srilankensis, with limited populations are confined to lowland rainforests, whereas Cyathea walkerae is distributed over a wider elevational range throughout the wet zone. Cyathea crinita shows a restricted distribution pattern at a high altitude range in the central highlands of the island. In this study $C$. gigantea was recorded additionally from lowland rain forests, though previously it was reported to be confined to submontane and montane ecosystems. The exotic Dicksonia antarctica and Cyathea australis have naturalised in forest clearings in Piduruthalagala forest. The results of this study provide baseline information on the distributional ecology of Sri Lankan Cyathea species to formulate conservation guidelines for this unique gene pool in Sri Lanka.

\section{ACKNOWLEDGEMENTS}

The authors gratefully acknowledge the Nagao Natural Environment Foundation, Japan, for financial support to conduct field-exploration. Support from the National Herbarium (PDA), Peradeniya, and the Forest Department, Department of Wildlife Conservation, Sri Lanka, is also highly appreciated.

\section{REFERENCES}

Ashton, P.M.S., Gunatilleke, C.V.S., Zoysa, N, E., Dassanayake, M.D., Gunatilleke, I.A.U.N. and Wijesundara, D.S.A. (1997). A Field Guide to the Common Trees and Shrubs of Sri Lanka. WHT Publication Private Limited, Colombo, Sri Lanka. 432 pp.

Beddome, R.H. (1883). Handbook to the ferns of British India, Ceylon and the Malay Peninsula. $2^{\text {nd }}$ edition. Thacker, Spink and Co. Calcutta. 110 pp.

Conant, D.S., Raubeson, L.A., Attwood, D.K., Perera, S., Zimmer, E.A., Sweere, J.A. and Stein, D.B. (1996). Phylogenetic and evolutionary implications of combined analysis of DNA and morphology in the Cyatheaceae. In: J.M. Camus, M. Gibby and R.J. Johns (Eds.), Pteridology in Perspective. Royal Botanical Gardens, Kew, United Kingdom. 132-248 pp.

Holttum, R.E. (1963). Cyatheaceae. Flora Malesiana 1: 65-176.

Holttum, R.E. (1965). Tree ferns of the genus Cyathea in Asia (excluding Malaysia). Kew Bulletin 19: 463-487.
Holttum, R.E. (1981). The tree ferns of Africa. Kew Bulletin 36: 463-483.

Hooker, W.J. (1846). Species Filicum. William Pamplin, London. 304 pp.

Hooker, W.J. and Baker, J.G. (1865). Synopsis Filicum. Robert Hardwicke, London. 482 pp.

Janssen, T., Bystriakova, N., Rakotondrainibe, F., Coomes, D., Labat, J.N. and Schneider, H. (2008). Neoendemism in Madagascan tree ferns results from recent, coincident diversification bursts. Evolution 62: 1876-1889.

Korall, P. and Pryer, K.M. (2014). Global biogeography of scaly tree ferns (Cyatheaceae): evidence for Gondwanan vicariance and limited transoceanic dispersal. Journal of Biogeography 41: 402-413.

Manickam, V.S. and Irudayaraj, V. (1992). Pteridophyte Flora of the Western Ghats South India. B. I. Publications, New Delhi. 653 pp.

MOE 2012. The National Red List 2012 of Sri Lanka: Conservation Status of the Fauna and Flora. Ministry of Environment, Colombo, Sri Lanka.viii + 476 pp.

Philcox, D. (2006). Cyatheaceae. In: Shaffer-Fehre, M. (Ed.). A Revised Handbook of the Flora of Ceylon. Vol. 15. Pteridophyta (Ferns and Fern Allies). Amerind Publishing Company Private Limited, New Delhi. 48$55 \mathrm{pp}$.

Ranil, R.H.G., Pushpakumara, D.K.N.G., Premakantha, K.T., Bostock,P.D. and Ebihara, A. (2014). Naturalization of Dicksonia antárctica Labill. in Pidurutalagala Mountain Forest Reserve and adjacent Eucalyptus plantation in Sri Lanka. Bulletin of the National Museum of Nature and Science. Series B, Botany. 40:107-112.

Ranil, R.H.G., Pushpakumara, D.K.N.G., Janssen, T., Fraser-Jenkins, C.R. and Wijesundara, D.S.A. (2011). Conservation priorities of tree ferns of Sri Lanka. Taiwania 56: 201-209.

Thwaites, G.H.K. (1864). Enumeratio Plantarum Zeylaniae: An enumeration of Ceylon Plants. London. 321-483 pp.

Tryon, R.M. and Gastony, G.J. (1975). The biogeography of endemism in the Cyatheaceae. Fern Gazette 11: 7379 . 